\title{
West Nile virus circulation in south-eastern Romania, 2011 to 2013
}

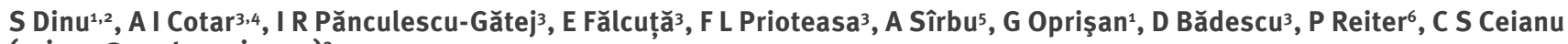
(ceianu@cantacuzino.ro) ${ }^{3}$

1. Molecular Epidemiology Laboratory, “Cantacuzino" National Institute of Research-Development for Microbiology and Immunology, Bucharest, Romania

2. Genetics Department, Faculty of Biology, University of Bucharest, Bucharest, Romania

3. Vector-Borne Infections and Medical Entomology Laboratory, "Cantacuzino" National Institute of Research-Development for Microbiology and Immunology, Bucharest, Romania

4. The European Programme for Public Health Microbiology Training (EUPHEM), European Centre for Disease Prevention and Control (ECDC), Stockholm, Sweden

5. National Institute of Public Health-National Centre for Surveillance and Control of Communicable Diseases, Bucharest, Romania

6. Unité Insectes et Maladies Infectieuses, Institut Pasteur, Paris, France

Citation style for this article:

Dinu S, Cotar AI, Pănculescu-Gătej IR, Fălcuță E, Prioteasa FL, Sîrbu A, Oprişan G, Bădescu D, Reiter P, Ceianu CS. West Nile virus circulation in south-eastern Romania, 2011 to 2013. Euro Surveill. 2015;20(20):pii=21130. Available online: http://www.eurosurveillance.org/ViewArticle.aspx?Articleld=21130

Article submitted on 10 July 2014 / published on 21 May 2015

Lineage 2 West Nile virus (WNV), previously found only in sub-Saharan Africa and Madagascar, was identified in Hungary in 2004 and has rapidly expanded in Europe in the past decade. Following a significant outbreak of West Nile fever with neurological cases caused by lineage 1 WNV in Romania in 1996, scattered cases have been recorded in the south-east of the country in each transmission season. Another outbreak, affecting a larger area and caused by lineage 2 WNV, was recorded in 2010. We analysed human sera from neuroinvasive West Nile fever cases and mosquitoes, sampled in south-eastern Romania between 2011 and 2013, for the presence of WNV genome, and obtained partial NS5 and envelope glycoprotein sequences. Human- and mosquito-derived WNV sequences were highly similar (99\%) to Volgograd 2007 lineage 2 WNV and differed from isolates previously detected in central and southern Europe. WNV was detected in one pool of Culex pipiens s.l. males, documenting vertical transmission. Lineage $4 \mathrm{WNV}$, of unknown pathogenicity to mammals, was found in the amphibian-feeding mosquito Uranotaenia unguiculata from the Danube Delta. Our results present molecular evidence for the maintenance of the same isolates of Volgograd 2007like lineage 2 WNV in south-eastern Romania between 2011 and 2013.

\section{Introduction}

WNV is by far the most widely distributed arbovirus. It belongs to the Japanese encephalitis antigenic complex of the family Flaviviridae, transmitted in an avian cycle by ornithophilic mosquitoes, mainly of the genus Culex. Mammals can also be infected, but are considered dead-end hosts because viraemia is generally too low to infect mosquitoes. Eighty per cent of human infections are asymptomatic, and less than $1 \%$ of clinical cases lead to neuroinvasive disease $[1,2]$.

Evidence of WNV circulation in Europe dates back to the early 1960 [3], lineage 1 isolates being responsible for the major outbreaks. A recent retrospective study indicates the circulation of lineage 2 WNV in birds (Sylvia nisoria) in Cyprus as early as 1968 [4]. Starting in 2004, lineage 2 WNV was identified in Hungary in birds of prey and was subsequently found again in Hungary in 2005 and in Austria in 2008 and 2009 [5-7]. Erroneously considered to be non-pathogenic for humans and with a distribution restricted only to sub-Saharan Africa and Madagascar [8], lineage 2 isolates caused outbreaks of WNV infection in Russia (2007), Greece (2010-2013), Romania (2010), Italy (2011, 2012), Serbia (2012, 2013) and Croatia $(2012,2013)$ [9-21].

Following the unprecedented epidemic of West Nile fever in south-eastern Romania in 1996 [22], caused by a lineage 1 strain [23], scattered human cases were recorded every year until a second significant outbreak occurred in 2010 [14]. In the latter, the affected area also included counties in the north-east of the country as well as in Transylvania, beyond the Carpathian mountains. The WNV detected in one human serum was lineage 2, closely similar to an isolate from a patient during the outbreak in Volgograd, Russia in 2007 [14].

According to the data provided by the National Institute of Public Health, laboratory-based surveillance of neuroinvasive West Nile infection was carried out in 2012 as previously described [14], and detected one probable and 14 confirmed cases among 128 suspected cases. The majority of West Nile fever cases were recorded in south-eastern Romania: seven in Bucharest 
Distribution of confirmed human cases of West Nile fever selected for molecular investigation and mosquito collection sites by county, Romania, 2011-2013
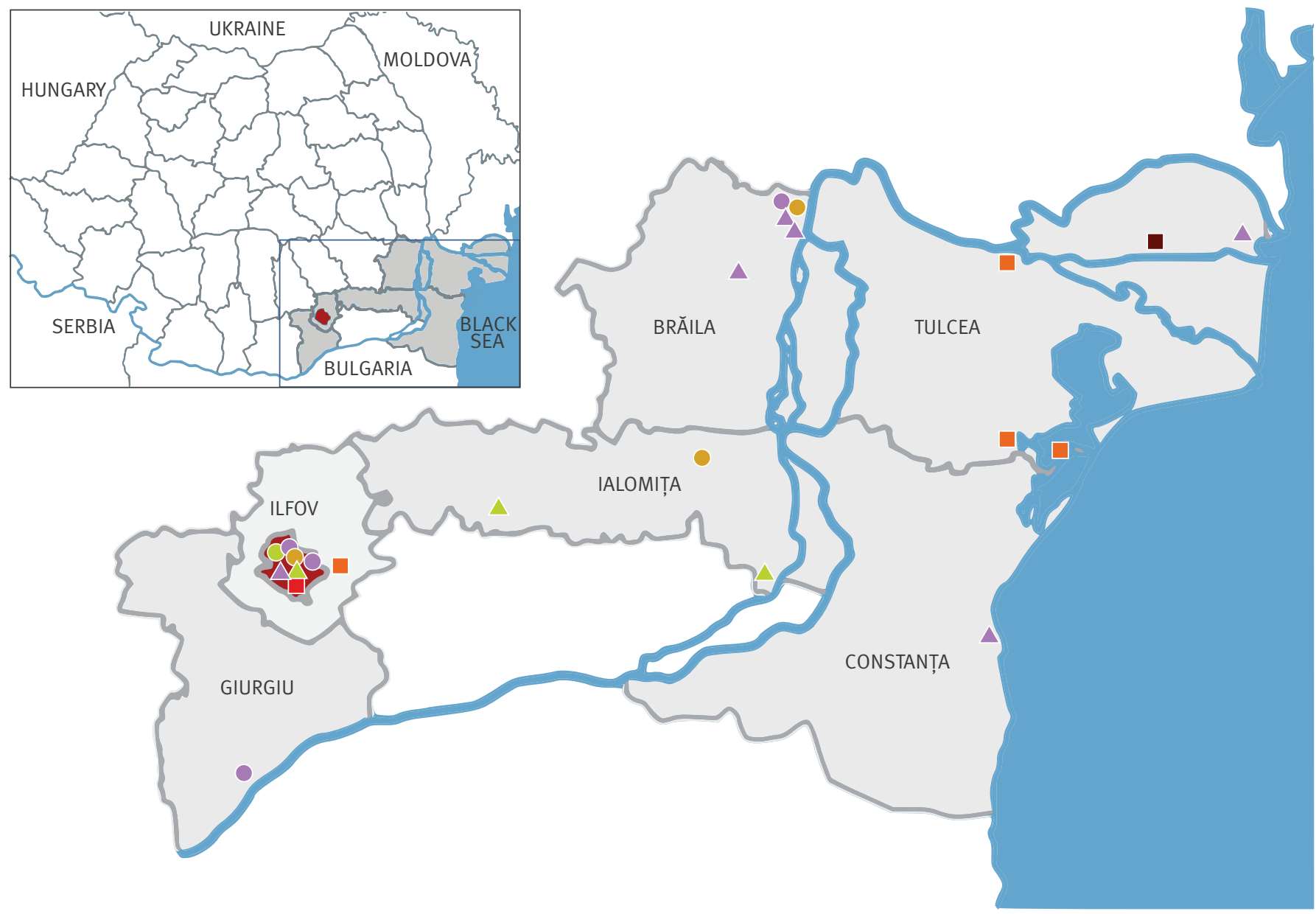

\section{Human cases 2012:}

Serologically confirmed cases selected for molecular analysis $(n=8)$

Confirmed cases with additional positive real-time RT-PCR $(n=4)$

Confirmed cases with positive real-time RT-PCR and NS5 sequence $(n=1)$

\section{Mosquitoes 2011-13:}

Collection site

Collection site where lineage 2 WNV was found

WNV: West Nile virus.

Counties shown at NUTS 3 level. Bucharest city is highlighted in russet.

city, two (one probable and one confirmed case) in the adjacent Ilfov county and in Ialomița (one case), Brăila (two cases), and Giurgiu (two cases) counties. A single case was also recorded in laşi, north-eastern Romania. Dates of onset were from 31 July to 11 September 2012. One death was recorded. In 2013, 22 confirmed and two probable cases were recorded among 142 suspected cases tested. Dates of onset were from 17 July to 19 September 2013. No deaths were reported (source: National Centre for Surveillance and Control of Communicable Diseases, National Institute of Public

\section{Human cases 2013:}

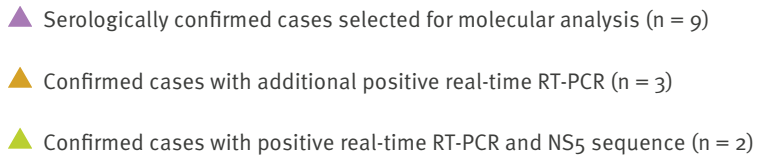

$\Delta$ Confirmed cases with positive real-time RT-PCR and NS5 sequence $(n=2)$

Collection site where lineage 2 WNV and lineage 4 WNV were found
Health). The majority of West Nile fever cases in that year also occurred in south-eastern Romania: Ialomița (four confirmed cases), Brăila (one probable and four confirmed cases), Tulcea (one probable case and two confirmed cases), Constanța (two confirmed cases), Bucharest city (one confirmed case) and the adjacent Ilfov county (one confirmed case). Another five cases were recorded in the north-eastern part of the country: Iaşi (two confirmed cases), Galați (two confirmed cases) and Bacău (one confirmed case). Bacău county is a new affected area. Three cases were recorded in 
Mosquito pools tested for West Nile virus genome, Romania, 2011-2013

\begin{tabular}{|l|c|c|c|}
\hline \multirow{2}{*}{ Collection area } & 2011 pools & 2012 pools & 2013 pools \\
\cline { 2 - 4 } & \multicolumn{2}{|c|}{ Tested/real-time RT-PCR-positive/sequenced } \\
\hline Tulcea county & $95 / 3 / 2$ & $388 / 70 / 10$ & $508 / 109 / 16$ \\
\hline Bucharest and surroundings & $9 / 0 / 0$ & $87 / 5 / 1$ & $98 / 2 / 1$ \\
\hline Total number of mosquito pools/total number of mosquitoes & $\mathbf{1 0 4 / 3 , 2 9 1}$ & $\mathbf{4 7 5 / 1 2 , 1 5 9}$ & $\mathbf{6 0 6 / 1 5 , 4 0 5}$ \\
\hline
\end{tabular}

the central part of the country (Mureş and Sibiu counties). Sera from these three cases were also tested for the presence of tick-borne encephalitis virus-specific antibodies because this flavivirus had previously been found to be circulating in this area.

Here we present the molecular characterisation of WNV circulating between 2011 and 2013 in humans and mosquitoes in south-eastern Romania, an area of endemic WNV circulation as shown by previous human and animal host surveillance studies $[24,25]$.

\section{Methods}

\section{Human cases}

Sera collected in 2012 and 2013 from patients with confirmed WNV neuroinvasive infection living in southeastern Romania were included in this study (Figure 1). Only samples collected in the first seven days post onset were selected for molecular investigation. Viral RNA was extracted from sera using QIAamp Viral RNA Mini Kit (Qiagen, Hilden, Germany).

\section{Mosquito collection and processing}

Adult mosquitoes were collected from two main areas: Tulcea county and Ilfov county including Bucharest. Four sites were investigated in Tulcea county: Mila 26 (in the core of the Danube Delta), Sălcioara and Grindul Lupilor (on the Razim lagoon shore) and Tulcea city (Figure 1). In Tulcea county, mosquitoes were collected by overnight capture in cylindrical traps baited with birds (chickens) and small rodents (guinea pigs) or collected from vegetation with a backpack aspirator. In the Danube Delta and the lagoon shore, collections were performed for periods of five to eight days in August and September 2011 and from May to October in 2012 and 2013. In Bucharest and the periurban area of the city, mosquito captures were performed between July and September (2011-13) using CDC Gravid Traps [26] and BG Sentinel Traps (Biogents AG, Germany). Mosquitoes were also collected from resting sites such as hallways of buildings using hand aspirator.

For RNA extraction (QIAamp Viral RNA Mini Kit, Qiagen, Hilden, Germany), the mosquitoes were processed as follows: they were identified using an entomological key [27], and pooled by species, sex and physiological age in pools never exceeding 50 individuals.

\section{Molecular analysis}

All samples (mosquito pools and human sera) were screened for the presence of WNV genome by one-step real-time RT-PCR using a commercial kit (West Nile Virus Real-TM, Sacace Biotechnologies). Positive samples were further tested by RT-PCR using primers VD8,

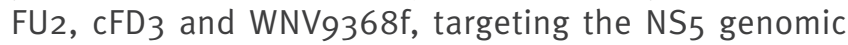
region $[5,28,29]$. When possible, a fragment spanning the envelope glycoprotein region (E) was amplified using primers WNVII 87of and WNVII 1630r [5]. All amplicons were sequenced (3130 Genetic Analyzer, Applied Biosystems) and the resulting sequences were aligned with ClustalW, BioEdit version 7.0.5.3 [30]. Maximum-likelihood phylogenetic analysis was conducted with Mega 6 software [31], which was also used for choosing the fittest nucleotide substitution model. The reliability of the phylogenetic trees was tested with 1,000 bootstrap replicates.

\section{Results}

\section{Human samples}

In 2012, serum samples from eight patients with serologically confirmed WNV infection, all in the acute phase of the disease, were tested by real-time RT-PCR.

\section{TABLE 2}

Mosquito species found to be positive for West Nile virus by sequencing and real-time RT-PCR, Romania, 2011-2013

\begin{tabular}{|c|c|c|c|}
\hline \multirow[b]{2}{*}{ Mosquito species } & 2011 pools & 2012 pools & 2013 pools \\
\hline & \multicolumn{3}{|c|}{$\begin{array}{l}\text { Sequenced/real-time RT-PCR-positive/pools } \\
\text { tested }\end{array}$} \\
\hline Culex pipiens s.l. & $2^{a} / 2 / 68$ & $5^{a} / 47^{b} / 343$ & $13^{a} / 51 / 369$ \\
\hline Culex modestus & $0 / 1 / 21$ & $3^{a} / 15 / 56$ & $0 / 46 / 131$ \\
\hline $\begin{array}{l}\text { Coquillettidia } \\
\text { richiardii }\end{array}$ & NA & $0 / 5 / 30$ & $2^{a} / 8 / 54$ \\
\hline Anopheles hyrcanus & NA & $1^{a} / 4 / 23$ & $0 / 3 / 21$ \\
\hline $\begin{array}{l}\text { Uranotaenia } \\
\text { unguiculata }\end{array}$ & NA & $2^{c} / 3 / 4$ & $2^{c / 2} / 4$ \\
\hline Ochlerotatus caspius & NA & $0 / 1 / 10$ & NA \\
\hline $\begin{array}{l}\text { Anopheles } \\
\text { maculipennis } \\
\text { complex }\end{array}$ & NA & NA & $0 / 1 / 18$ \\
\hline
\end{tabular}

NA: not applicable.

a West Nile virus lineage 2 .

b 46 pools of females and one pool of males.

West Nile virus lineage 4 
FIGURE 2

Phylogenetic tree of lineage 2 West Nile viruses based on NS5 partial sequences, Romania, 2011-2013

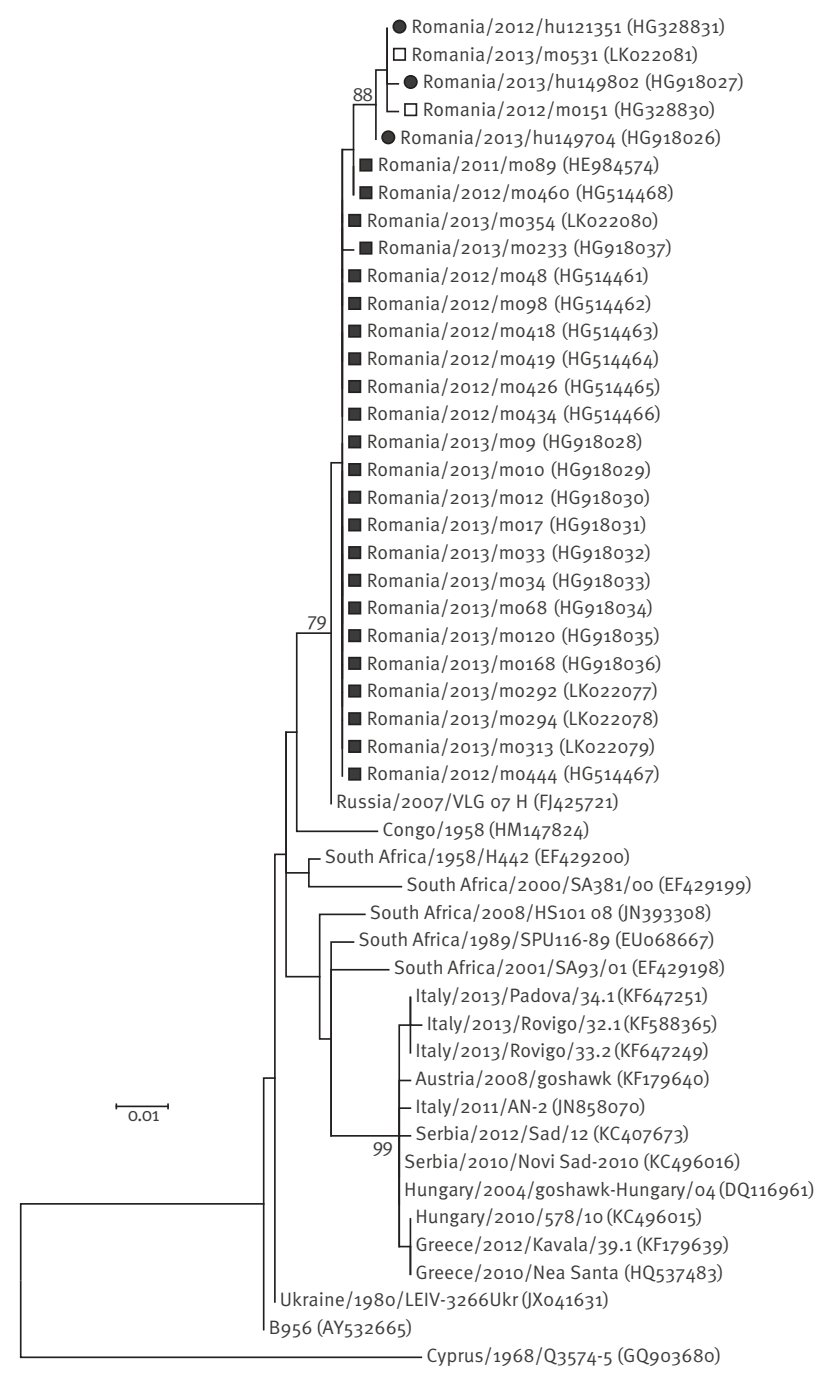

Black squares: sequences obtained in this study from mosquitoes collected in Danube Delta (Mila 26); white squares: sequences obtained in this study from mosquitoes collected in Bucharest city; black circles: sequences obtained in this study from human sera. Numbers at nodes represent the bootstrap percentages (values $<70 \%$ are not shown).

The analysis was conducted on a $466 \mathrm{nt}$ sequence (nt positions 9,463-9,928 in isolate Reb_VLG_07_H, GenBank acc. no. FJ425721) using maximum-likelihood method, Kimura 2-parameter model, 1,000 bootstrap replicates. A sequence obtained from strain Q3574-5 (Cyprus, 1968; GenBank acc. no. GQ903680) was used as an outgroup.

All patients lived in south-eastern Romania: Bucharest city (four cases) and the counties of Brăila (two cases), Giurgiu (one case) and lalomița (one case). WNV genome was detected by real-time RT-PCR (Ct values: 28.1-34.4) in four of these samples: Bucharest city (two cases), Brăila (one case) and lalomița (one case) (Figure 1).

In 2013, nine serum samples fulfilled the inclusion criteria: Bucharest city (two cases) and Brăila (three cases), Constanța (one case), lalomița (two cases), Tulcea (one case) counties. WNV genome was found in the samples from one patient living in Bucharest city and two from lalomița county (Ct values: 29.85-33.65) (Figure 1).

In summary, during the two years of investigation, we detected seven positive serum samples in the PCR screening assay. Only one sample from 2012 and two from 2013 yielded an NS5 amplicon suitable for obtaining a DNA sequence. None of the above samples yielded an E amplicon suitable for sequencing.

\section{Mosquito samples}

In 2011 to 2013, we collected and analysed 30,855 mosquitoes. About $75 \%$ of these insects were captured in the Danube Delta, and 189 of the 1,185 mosquito pools tested were real-time RT-PCR-positive for WNV genome (Table 1). As expected, the majority of these pools consisted of Culex pipiens s.l., followed by $C x$. modestus. Other mosquito species were also found real-time RT-PCR-positive for WNV genome (Table 2). Of interest was the detection of WNV genome in a pool of Cx. pipiens s.l. males collected in 2012 in Bucharest. Unfortunately, no amplicon for sequencing could be obtained from this sample. During the three years of the study, we obtained 30 DNA sequences for WNV NS5 derived from mosquito pools containing $C_{x}$. pipiens s.l., Cx. modestus, Anopheles hyrcanus, Coquillettidia richiardii and Uranotaenia unguiculata species (Table 2). Two partial E sequences were also obtained from Cx. pipiens s.l. mosquitoes collected in the Danube Delta in 2011 and 2012.

In 2012 and 2013, we identified the WNV lineage 2 genome in sera collected from three patients with meningoencephalitis living in south-eastern Romania. The first detection was in August 2012 in the acute phase serum of a resident of Bucharest. In September 2013, similar WNV isolates were found in a patient living in Bucharest and in a resident of lalomița county.

Our phylogenetic analysis based on $\mathrm{NS}_{5}$ partial sequences (Figure 2) indicated that the viruses in circulation in Romania between 2011 and 2013 were very similar to a lineage 2 WNV isolated during the outbreak in Volgograd, Russia, in 2007; all our mosquito and human-derived sequences were more than $99 \%$ similar to that isolate. The same strain of lineage 2 WNV, $99 \%$ identical to Volgograd 2007, has been circulating in Bucharest since 2010 [14]. Although the investigated genomic region is strongly conserved, a bootstrap value of $79 \%$ from the node relating the Romanian sequences to the Volgograd 2007 isolate indicated the robustness of the analysis. It is worth mentioning that the sequences obtained from human specimens clustered with two sequences derived from two pools of Cx. pipiens s.l. females collected in 2012 and 2013 in Bucharest area. All sequences derived from mosquitoes collected in the same ecosystem (Danube Delta, Mila 26 collecting site), regardless of the year of collection, clustered in a single subclade comprised of three 


\section{FIGURE 3}

Phylogenetic tree of lineage 2 West Nile viruses based on envelope glycoprotein (E) sequences, Romania, 2011-2012

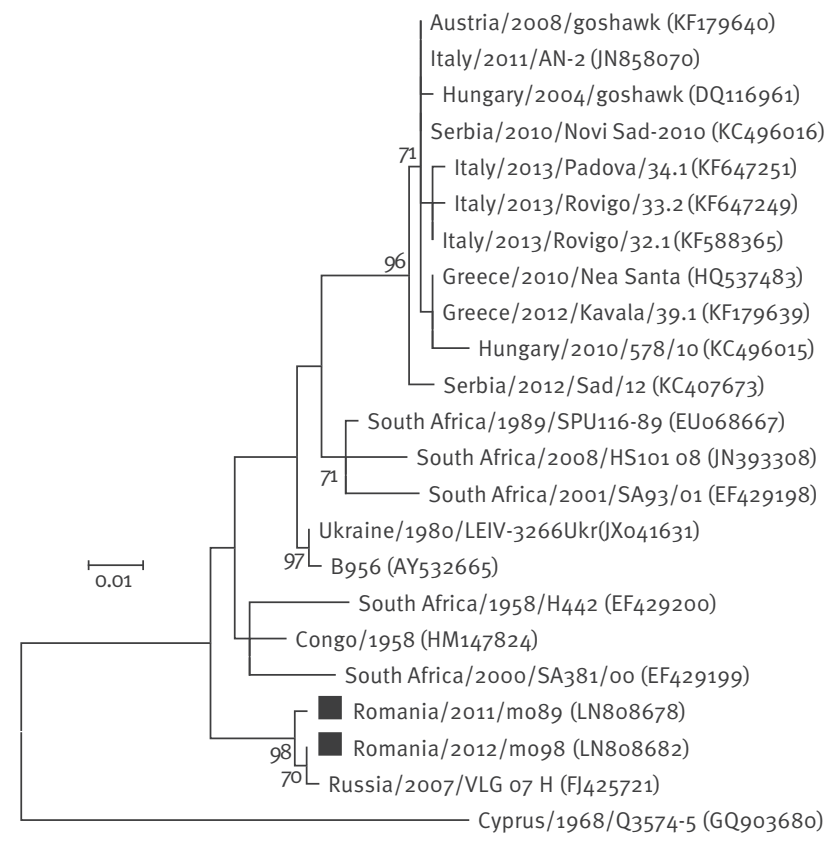

Black squares: sequences obtained in this study from mosquitoes collected in Danube Delta (Mila 26). Numbers at nodes represent the bootstrap percentages (values $<70 \%$ are not shown).

The analysis was conducted on a 460 nt sequence (positions 9341,393 in isolate Reb_VLG_07_H, GenBank acc. no. FJ425721) using maximum-likelihood method, Tamura-Nei model, 1,000 bootstrap replicates. A sequence obtained from strain Q3574-5 (Cyprus, 1968; GenBank acc. no. GQ903680) was used as an outgroup.

major groups that differed by a small number of synonymous and non-synonymous nucleotide substitutions.

Furthermore, the phylogenetic analysis based on E partial sequences confirmed the topology of the NS 5 tree, placing the Romanian sequences in the same clade with the isolate obtained in 2007 in Volgograd, Russia (Figure 3).

An interesting finding was the detection of lineage 4 WNV in four pools of Ur. unguiculata mosquito collected in 2012 and 2013 (Figure 4). Similar strains have already been reported by Russian authors from this mosquito species, known to feed on amphibians, and from frogs collected in Volga Delta, as well as from Dermacentor marginatus ticks collected in the Caucasus [32].

NS5 and E partial sequences described in this study are available in GenBank under the following accession numbers: HE984574, HE984575, HG328830, HG328831, HG514461-HG514468,HG918026-HG918037, LKo22077-LKo22085, LN808678 and LN808682.

\section{Discussion}

As shown by sequencing, Volgograd 2007-like lineage 2 WNV isolates were found both in patients with neurological WNV infections (2012 and 2013) and in mosquito vectors (2011-13) in south-eastern Romania.

In 2011, Volgograd 2007-like isolates were detected in two pools of $C x$. pipiens s.l. mosquitoes collected from the Danube Delta. In 2012, in this area, the same virus was found in nine mosquito pools consisting of specimens belonging to three species: $C x$. pipiens s.l. (five pools) and $C x$. modestus (three pools) mosquitoes, already known as WNV principal vectors in Europe [23,33], but also in An. hyrcanus (one pool). The results for 2013 in the Danube Delta indicated the presence of the same lineage 2 WNV in 15 mosquito pools belonging to two species: $C x$. pipiens s.l. (13 pools) and Cq. richiardii (two pools). Also, in 2012 and 2013, we detected Volgograd 2007-like isolates in two pools of $C x$. pipiens s.l. mosquitoes collected in Bucharest city. In Europe, WNV has been previously detected in Cq. richiardii and An. hyrcanus in the Volga Delta [32].

WNV genome was also detected in one pool of $C x$. pipiens s.l. males collected in 2012 in Bucharest city. To our knowledge, this is the first direct field evidence of vertical transmission of WNV in Europe. WNV has previously been detected in Culex spp. males in Kenya [34] and in North America $[35,36]$. Vertical transmission has also been documented in overwintering Culex spp. females [37] and is thought to represent a mechanism for WNV maintenance [38]. The persistence of WNV in a temperate climate may be achieved by overwintering of infected arthropod vectors and by long-term infection in birds [39], and may explain endemic WNV circulation. Indeed, maintenance of this WNV lineage 2 Volgograd-like strain in the same area for three years has been documented by us.

Initially considered to be non-pathogenic for humans [40], lineage 2 WNV was detected in Europe in 2004, in a goshawk (Accipiter gentilis) in south-eastern Hungary. It then became established and caused sporadic cases of infection in wild birds, sheep, horses and humans $[5,41]$. In the following years, similar isolates were detected in birds of prey in eastern Austria [7] and in Culex sp. mosquitoes and collared doves (Streptopelia decaocto) in Italy [42]. During the period from 2010 to 2013, lineage 2 WNV isolates similar to those in central Europe caused major outbreaks in Greece [10-13]. The Greek isolates from 2010 and 2012 had unique amino acid substitutions (V119l in NS2B; H249P in NS3; S14G, T49A and $\mathrm{V}_{113} \mathrm{M}$ in NS4) compared with the isolates from Hungary and Austria, which might explain their high pathogenicity [43].

Although there is a high degree of similarity (96\%) between our sequences and those obtained from other isolates circulating in central and southern Europe in recent years, our sequences clearly clustered with the Volgograd 2007 isolate. This distribution of a distinct strain of lineage 2 WNV in eastern Europe may be related to the Mediterranean/Black Sea flyway of northward migrating birds, as it is documented that 


\section{FIGURE 4}

Phylogenetic tree of lineage 4 West Nile viruses based on NS5 partial sequences, Romania, 2012-2013

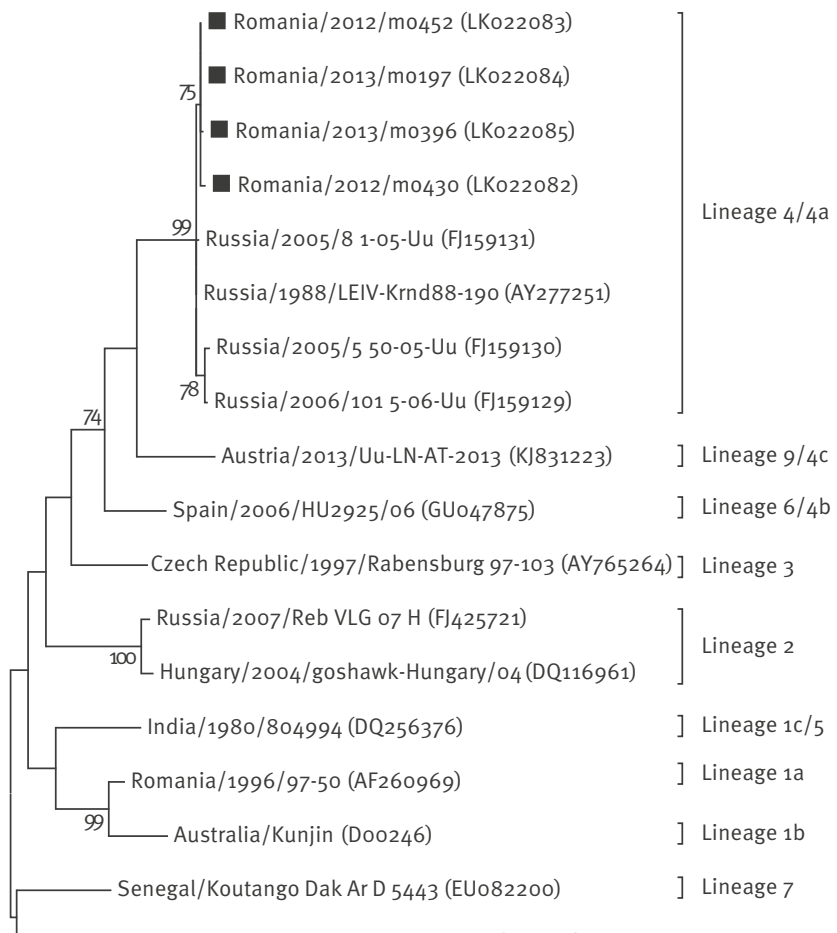

Japanese encephalitis virus (L48961)

$\overline{0.05}$

Black squares: sequences obtained in this study from mosquitoes collected in Danube Delta (Mila 26). Numbers at nodes represent the bootstrap percentages (values $<70 \%$ are not shown).

Analysis was conducted on a 365 nt sequence (positions 9,4799,843 , in isolate LEIV-Krnd88-190, GenBank acc. no. AY277251) using maximum-likelihood method, Kimura 2-parameter model, 1,000 bootstrap replicates. A sequence obtained from a Japanese encephalitis virus isolate (GenBank acc. no. L48961) was used as an outgroup.

Lineages were defined as previously proposed [48].

birds play a crucial role in the spread of the virus [44]. The Volga and Danube deltas are also connected by autumn migration, and there is evidence that WNV may be introduced as birds travel to their owerwintering sites in Africa [45]. Our findings, together with other published data suggest that at least two independent introduction events of two different lineage 2 WNV strains occurred in Europe, followed by their subsequent endemisation.

The presence of WNV lineage 4 identified in two consecutive years (2012-13) in four pools of Ur. unguiculata mosquitoes captured in the Danube Delta is worth mentioning. Studies between 2002 and 2006 in the Volga Delta, an ecosystem similar to that of the Danube Delta, demonstrated the presence of WNV lineage 4 in Ur. unguiculata and in the lake frog Rana ridibunda [46]. Lineage 4 (isolate LEIV-Krnd88-190) was first identified in 1988 in Dermacentor marginatus ticks collected in the north-west Caucasus [32]. Attempts to propagate the virus in suckling mice or in mammalian or mosquito cell lines have failed. The strains of this lineage seem to be associated with arthropods and amphibians and their pathogenicity for vertebrates is not characterised [46]. Recent studies conducted in Spain and Austria $[47,48]$ reported two WNV strains of unknown pathogenicity which can be assigned to new lineages closely related to lineage 4 . The Spanish WNV was found in $C x$. pipiens mosquitoes, while the Austrian virus was detected in Ur. unguiculata mosquitoes. It has been proposed based on NS5 partial sequences that WNV isolates previously found in Ur. unguiculata mosquitoes and Dermacentor marginatus ticks from Russia should be grouped in a clade designated lineage 4 or $4 \mathrm{a}$, while the sequence from Spain should be classified in lineage $4 \mathrm{~b}$ or 6 , and the WNV sequence identified in mosquitoes from Austria should be comprised in lineage $4 \mathrm{C}$ or 9 [48]. As shown in Figure 4, WNV sequences derived from Ur. unguiculata mosquitoes collected in Romania clearly cluster in the proposed lineage 4/4a, along with the Russian isolates. It has been speculated that less or non-pathogenic WNV strains may infect birds, conferring them immunity, thus limiting the spread of pathogenic strains [47].

\section{Conclusion}

The neurovirulent strain Volgograd 2007-like of lineage 2 WNV has been circulating in Romania in mosquito populations and causing disease in humans since at least 2010, as shown by previous [14] and present findings. The distribution of this strain may be linked to the flyways connecting Africa to eastern Europe and the Danube and Volga deltas, followed by virus maintenance and endemic circulation in the region.

\section{Acknowledgments}

This study was funded by European Union (EU) grant FP7261504 EDENext and is catalogued by the EDENext Steering Committee as EDENext256 (www.edenext.eu). The contents of this publication are the sole responsibility of the authors and do not necessarily reflect the views of the European Commission.

\section{Conflict of interest}

None declared.

Authors' contributions

SD, IRPG and GO set up and performed molecular diagnostic, sequencing and phylogenetic analysis. IRPG, DB and CSC performed serological diagnosis of human cases. AIC and IRPG performed molecular detection tests in mosquitoes pools. AS managed West Nile fever surveillance program. FLP and EF performed field collection of mosquitoes, their identification and processing for molecular analyses. SD and CSC wrote the paper. PR coordinated the entomological work and provided a critical review of the manuscript. 


\section{References}

1. Colpitts TM, Conway MJ, Montgomery RR, Fikrig E. West Nile Virus: biology, transmission, and human infection. Clin Microbiol Rev. 2012;25(4):635-48. http://dx.doi.org/10.1128/ CMR.00045-12 PMID:23034323

2. Beck C, Jimenez-Clavero MA, Leblond A, Durand B, Nowotny $\mathrm{N}$, Leparc-Goffart I, et al. Flaviviruses in Europe: complex circulation patterns and their consequences for the diagnosis and control of West Nile disease. Int J Environ Res Public Health. 2013;10(11):6049-83. http://dx.doi.org/10.3390/ ijerph10116049 PMID:24225644

3. Calistri P, Giovannini A, Hubalek Z, Ionescu A, Monaco F, Savini G, et al. Epidemiology of west nile in europe and in the mediterranean basin. Open Virol J. 2010;4:29-37. PMID:20517490

4. McMullen AR, Albayrak H, May FJ, Davis CT, Beasley DW, Barrett AD. Molecular evolution of lineage 2 West Nile virus J Gen Virol. 2013;94(Pt 2):318-25. http://dx.doi.org/10.1099/ vir.0.046888-o PMID:23136360

5. Bakonyi T, Ivanics E, Erdélyi K, Ursu K, Ferenczi E, Weissenböck $\mathrm{H}$, et al. Lineage 1 and 2 strains of encephalitic West Nile virus, central Europe. Emerg Infect Dis. 2006;12(4):618-23. http:// dx.doi.org/10.3201/eid1204.051379 PMID:16704810

6. Erdélyi K, Ursu K, Ferenczi E, Szeredi L, Rátz F, Skáre J, et al. Clinical and pathologic features of lineage 2 West Nile virus infections in birds of prey in Hungary. Vector Borne Zoonotic Dis. 2007;7(2):181-8. http://dx.doi.org/10.1089/vbz.2006.0586 PMID:17627436

7. Wodak E, Richter S, Bagó Z, Revilla-Fernández S, Weissenböck $\mathrm{H}$, Nowotny $\mathrm{N}$, et al. Detection and molecular analysis of West Nile virus infections in birds of prey in the eastern part of Austria in 2008 and 2009. Vet Microbiol. 2011;149(3-4):358-66 http://dx.doi.org/10.1016/j.vetmic.2010.12.012 PMID:21276665

8. Berthet FX, Zeller HG, Drouet MT, Rauzier J, Digoutte JP, Deubel V. Extensive nucleotide changes and deletions within the envelope glycoprotein gene of Euro-African West Nile viruses. J Gen Virol. 1997;78(Pt 9):2293-7. PMID:9292017

9. Platonov AE, Fedorova MV, Karan LS, Shopenskaya TA Platonova OV, Zhuravlev VI. Epidemiology of West Nile infection in Volgograd, Russia, in relation to climate change and mosquito (Diptera: Culicidae) bionomics. Parasitol Res. 2008;103(S1) Suppl 1;S45-53. http://dx.doi.org/10.1007/ so0436-008-1050-o PMID:19030885

10. Papa A, Xanthopoulou K, Gewehr S, Mourelatos S. Detection of West Nile virus lineage 2 in mosquitoes during a human outbreak in Greece. Clin Microbiol Infect. 2011;17(8):11768o. http://dx.doi.org/10.1111/j.1469-0691.2010.03438.x PMID:21781205

11. Chaskopoulou A, Dovas C, Chaintoutis S, Bouzalas I, Ara G, Papanastassopoulou M. Evidence of enzootic circulation of West Nile virus (Nea Santa-Greece-2010, lineage 2), Greece, May to July 2011. Euro Surveill. 2011;16(31):19933. PMID:21871217

12. Chaintoutis SC, Chaskopoulou A, Chassalevris T, Koehler PG, Papanastassopoulou M, Dovas CI. West Nile virus lineage 2 strain in Greece, 2012. Emerg Infect Dis. 2013;19(5):827-9. http://dx.doi.org/10.3201/eid1905.121418 PMID:23697609

13. Papa A, Testa T, Papadopoulou E. Detection of West Nile virus lineage 2 in the urine of acute human infections. J Med Virol. 2014;86(12):2142-5. PMID:24760617

14. Sirbu A, Ceianu CS, Panculescu-Gatej RI, Vazquez A, Tenorio $A$, Rebreanu R, et al. Outbreak of West Nile virus infection in humans, Romania, July to October 2010. Euro Surveill. 2011;16(2):19762. PMID:21251489

15. Bagnarelli P, Marinelli K, Trotta D, Monachetti A, Tavio M, Del Gobbo R, et al. Human case of autochthonous West Nile virus lineage 2 infection in Italy, September 2011. Euro Surveill. 2011;16(43):20002. PMID:22085600

16. Magurano F, Remoli ME, Baggieri M, Fortuna C, Marchi A, Fiorentini $C$, et al. Circulation of West Nile virus lineage 1 and 2 during an outbreak in Italy. Clin Microbiol Infect. 2012;18(12):E545-7. http://dx.doi.org/10.1111/1469-0691.12018 PMID:23020657

17. Barzon L, Pacenti M, Franchin E, Lavezzo E, Masi G, Squarzon $\mathrm{L}$, et al. Whole genome sequencing and phylogenetic analysis of West Nile virus lineage 1 and lineage 2 from human cases of infection, Italy, August 2013. Euro Surveill. 2013;18(38):20591. http://dx.doi.org/10.2807/1560-7917.ES2013.18.38.20591 PMID:24084339

18. Popović N, Milošević B, Urošević A, Poluga J, Lavadinović L, Nedelijković J, et al. Outbreak of West Nile virus infection among humans in Serbia, August to October 2012. Euro Surveill. 2013;18(43):20613. http://dx.doi.org/10.2807/15607917.ES2013.18.43.20613 PMID:24176618
19. Kemenesi G, Krtinić B, Milankov V, Kutas A, Dallos B, Oldal $M$, et al. West Nile virus surveillance in mosquitoes, April to October 2013, Vojvodina province, Serbia: implications for the 2014 season. Euro Surveill. 2014;19(16):20779. http://dx.doi. org/10.2807/1560-7917.ES2014.19.16.20779 PMID:24786260

20. Pem-Novosel I, Vilibic-Cavlek T, Gjenero-Margan I, Pandak $\mathrm{N}$, Peric L, Barbic L, et al. First outbreak of West Nile virus neuroinvasive disease in humans, Croatia, 2012. Vector Borne Zoonotic Dis. 2014;14(1):82-4. http://dx.doi.org/10.1089/ vbz.2012.1295 PMID:24283515

21. Kurolt IC, Krajinović V, Topić A, Kuzman I, Baršić B, Markotić A. First molecular analysis of West Nile virus during the 2013 outbreak in Croatia. Virus Res. 2014;189:63-6. http://dx.doi. org/10.1016/j.virusres.2014.04.017 PMID:24809948

22. 〈jrn〉22. Tsai TF, Popovici F, Cernescu C, Campbell GL, Nedelcu NI. West Nile encephalitis epidemic in southeastern Romania. Lancet. 1998;352(9130):767-71. http://dx.doi.org/10.1016/ S0140-6736(98)03538-7 PMID:9737281</jrn〉

23. Savage HM, Ceianu C, Nicolescu G, Karabatsos N, Lanciotti R, Vladimirescu A, et al. Entomologic and avian investigations of an epidemic of West Nile fever in Romania in 1996, with serologic and molecular characterization of a virus isolate from mosquitoes. Am J Trop Med Hyg. 1999;61(4):600-11. PMID:10548295

24. Ceianu CS, Ungureanu A, Nicolescu G, Cernescu C, Nitescu L, Tardei G, et al. West nile virus surveillance in Romania: 1997-2000. Viral Immunol. 2001;14(3):251-62. http://dx.doi. org/10.1089/088282401753266765 PMID:11572635

25. Ludu Oslobanu EL, Mihu-Pintilie A, Anită D, Anita A, Lecollinet $S$, Savuta G. West Nile virus reemergence in Romania: a serologic survey in host species. Vector Borne Zoonotic Dis. 2014;14(5):330-7. http://dx.doi.org/10.1089/vbz.2013.1405 PMID:24745699

26. Reiter P. A revised version of the CDC Gravid Mosquito Trap. J Am Mosq Control Assoc. 1987;3(2):325-7. PMID:3504918

27. Becker N, Petric ${ }^{\prime}$ D, Zgomba M, Boase C, Dahl C, Madon M, et al. Mosquitoes and their control. Berlin Heidelberg: SpringerVerlag; 2010.

28. Pierre V, Drouet MT, Deubel V. Identification of mosquitoborne flavivirus sequences using universal primers and reverse transcription/polymerase chain reaction. Res Virol. 1994;145(2):93-104. http://dx.doi.org/10.1016/So9232516(07)80011-2 PMID:7520190

29. Kuno G, Chang GJ, Tsuchiya KR, Karabatsos N, Cropp CB. Phylogeny of the genus Flavivirus. J Virol. 1998;72(1):73-83. PMID:9420202

30. Hall TA. BioEdit: a user-friendly biological sequence alignment editor and analysis program for Windows 95/98/NT. Nucleic Acids Symp. Ser 01/1999;41:95-8.

31. Tamura K, Stecher G, Peterson D, Filipski A, Kumar S. MEGA6: Molecular Evolutionary Genetics Analysis version 6.0. Mol Biol Evol. 2013;30(12):2725-9. http://dx.doi.org/10.1093/molbev/ mst197 PMID:24132122

32. Lvov DK, Butenko AM, Gromashevsky VL, Kovtunov Al, Prilipov $A G$, Kinney R, et al. West Nile virus and other zoonotic viruses in Russia: examples of emerging-reemerging situations. Arch Virol Suppl. 2004; (18):85-96. PMID:15119764

33. Balenghien T, Vazeille M, Grandadam M, Schaffner F, Zeller $\mathrm{H}$, Reiter P, et al. Vector competence of some French Culex and Aedes mosquitoes for West Nile virus. Vector Borne Zoonotic Dis. 2008;8(5):589-95. http://dx.doi.org/10.1089/ vbz.2007.0266 PMID:18447623

34. Miller BR, Nasci RS, Godsey MS, Savage HM, Lutwama JJ, Lanciotti RS, et al. First field evidence for natural vertical transmission of West Nile virus in Culex univittatus complex mosquitoes from Rift Valley province, Kenya. Am J Trop Med Hyg. 2000;62(2):240-6. PMID:10813479

35. Fechter-Leggett E, Nelms BM, Barker CM, Reisen WK. West Nile virus cluster analysis and vertical transmission in Culex pipiens complex mosquitoes in Sacramento and Yolo Counties, California, 2011. J Vector Ecol. 2012;37(2):442-9. http://dx.doi. org/10.1111/j.1948-7134.2012.00248.x PMID:23181869

36. Unlu I, Mackay AJ, Roy A, Yates MM, Foil LD. Evidence of vertical transmission of West Nile virus in field-collected mosquitoes. J Vector Ecol. 2010;35(1):95-9. http://dx.doi. org/10.1111/j.1948-7134.2010.00064.x PMID:20618654

37. Farajollahi A, Crans WJ, Bryant P, Wolf B, Burkhalter KL, Godsey MS, et al. Detection of West Nile viral RNA from an overwintering pool of Culex pipens pipiens (Diptera: Culicidae) in New Jersey, 2003. J Med Entomol. 2005;42(3):490-4. http:// dx.doi.org/10.1093/jmedent/42.3.490 PMID:15962803

38. Reisen WK, Fang Y, Lothrop HD, Martinez VM, Wilson J, Oconnor P, et al. Overwintering of West Nile virus in Southern California. J Med Entomol. 2006;43(2):344-55. http://dx.doi. org/10.1093/jmedent/43.2.344 PMID:16619621 
39. Reisen WK. Ecology of West Nile virus in North America. Viruses. 2013;5(9):2079-105. http://dx.doi.org/10.3390/ v5092079 PMID:24008376

40. Venter M, Swanepoel R. West Nile virus lineage 2 as a cause of zoonotic neurological disease in humans and horses in southern Africa. Vector Borne Zoonotic Dis. 2010;10(7):659-64. http://dx.doi.org/10.1089/vbz.2009.0230 PMID:20854018

41. Bakonyi T, Ferenczi E, Erdélyi K, Kutasi O, Csörgő T, Seidel B, et al. Explosive spread of a neuroinvasive lineage 2 West Nile virus in Central Europe, 2008/2009. Vet Microbiol. 2013;165(12):61-70. http://dx.doi.org/10.1016/j.vetmic.2013.03.005 PMID:23570864

42. Savini G, Capelli G, Monaco F, Polci A, Russo F, Di Gennaro $A$, et al. Evidence of West Nile virus lineage 2 circulation in Northern Italy. Vet Microbiol. 2012;158(3-4):267-73.

43. Barzon L, Papa A, Pacenti M, Franchin E, Lavezzo E, Squarzon L, et al. Genome sequencing of West Nile Virus from human cases in Greece, 2012. Viruses. 2013;5(9):2311-9. http://dx.doi. org/10.3390/v5092311 PMID:24064795

44. Malkinson $M$, Banet $C$. The role of birds in the ecology of West Nile virus in Europe and Africa. Curr Top Microbiol Immunol. 2002;267:309-22. http://dx.doi.org/10.1007/978-3-642-594038 15 PMID:12082995

45. Pradier S, Lecollinet S, Leblond A. West Nile virus epidemiology and factors triggering change in its distribution in Europe. Rev Sci Tech. 2012;31(3):829-44. PMID:23520737

46. Shopenskaia TA, Fedorova MV, Karan LS, Frolov AI, Malenko GV, Levina LS et al. New variant of West Nile virus and its potential epizootic and epidemiological significance. Epidemiologiia i Infektsionnye Bolezni. 2008;(5): 38-44. (In Russ.)

47. Vázquez A, Sanchez-Seco MP, Ruiz S, Molero F, Hernandez L, Moreno J, et al. Putative new lineage of west nile virus, Spain. Emerg Infect Dis. 2010;16(3):549-52. http://dx.doi.org/10.3201/ eid1603.091033 PMID:20202444

48. Pachler K, Lebl K, Berer D, Rudolf I, Hubalek Z, Nowotny N. Putative New West Nile Virus Lineage in Uranotaenia unguiculata Mosquitoes, Austria, 2013. Emerg Infect Dis. 2014;20(12):2119-22 